\title{
STUDY ON MECHANICAL PROPERTIES OF CONCRETE WITH INDUSTRIAL WASTES
}

\author{
Dharani .N $\mathbf{N}^{\mathbf{1}}$, Prince Arulraj . $\mathbf{G}^{\mathbf{2}}$ Goutham .J $\mathbf{J}^{\mathbf{3}}$ \\ ${ }^{1}$ Assistant Professor, Department of Civil Engineering, SNS College of Technology, Sathy Main Road, \\ Vazhiyampalayam Pirivu, Coimbatore - 35, Tamil Nadu, India. \\ ${ }^{2}$ Professor and Dean, Department of Civil Engineering, SNS College of Technology, Sathy Main Road, \\ Vazhiyampalayam Pirivu, Coimbatore - 35, Tamil Nadu, India. \\ ${ }^{3}$ PG Student (Structural Engineering), Department of Civil Engineering, SNS College of Technology, Sathy Main \\ Road, Vazhiyampalayam Pirivu, Coimbatore - 35, Tamil Nadu, India
}

\begin{abstract}
Utilization of Industrial waste, construction waste, agriculture waste, commercial waste etc... In concrete plays a vital role in minimizing the disposal problems. Over 300 million tons of industrial wastes are being produced per annum by chemical and agricultural process in India. These materials poses problems of disposal, health hazards and aesthetic problem. Hypo Sludge $(H S)$ is a waste material produced from paper industry that can used as a cement replacement material in concrete since the lime content in the sludge is large. Copper slag is a waste material produced from copper manufacturing process and this can be used as a replacement material for fine aggregate (sand) since the particle size similar to sand. During the present study, an attempt had been made to study the mechanical properties of concrete in which Hypo sludge and Copper slag were as a replacement material for cement and fine aggregate respectively. Replacement percentage used during this study were 10\%, 20\% and 30\% of Hypo sludge for cement. Fine aggregate was replaced with 30\%, 40\% and 50\% of Copper slag. Compressive strength of cubes were found on $7^{\text {th }}, 28^{\text {th }}$ and $56^{\text {th }}$ days. Split tensile strengths of the cylinders were found on $28^{\text {th }}$ and $56^{\text {th }}$ days. Flexural strengths of prism specimens were found on $28^{\text {th }}$ day. It has been found that usage of Hypo sludge and Copper slag as a replacement material has beneficial effects on the Mechanical properties of concrete.
\end{abstract}

Keywords: Hypo sludge, Copper slag, Compressive strength, Split tensile strength, Flexural strength.

\section{INTRODUCTION}

Concrete is a strong and versatile construction material. It is a mixture of cement, sand, aggregate water and admixtures. The manufacturing of using Portland cement (PC) which is the main ingredient of concrete releases a large amount of greenhouse gases specially $\mathrm{CO}_{2}$. On the other side dumping of wastes produced from industries, Corporations or municipalities causes major environmental issues. To minimizing these effects, researchers are trying to use waste materials from industries as replacement material for cement or coarse aggregate or fine aggregate. Use of Industrial waste materials in concrete may change the workability and hardened properties based on the nature of the waste materials. Fly ash, Bottom ash, Bagasse ash, Ground Granulated Blast furnace Slag, Metakaolin, Silica fume etc... are being used as replacement materials for cement. Foundry sand, silica sand, quarry dust, manufactured sand etc... are being used as replacement material for fine aggregate. During this present investigation, an attempt has been made to simultaneous replacement of cement with hypo sludge and fine aggregate with copper slag.

\section{LITERATURE REVIEW}

Arivalagan .S, determined the Mechanical properties of concrete with copper slag as a replacement material for fine aggregate and the replacement percentage was varied from 0 to $100 \%$. He concluded that $40 \%$ replacement of fine aggregate with copper slag yielded good compressive and flexural strengths and it is reported that the optimum replacement percentage is 40 .

Brindha .D and Nagan .S, found the mechanical properties of concrete with copper slag as a replacement material for fine aggregate. They reported that upto $40 \%$ replacement, compressive and flexural strengths increases beyond that, strength was found to decrease.

Pavitha .G, et.al, determined the mechanical properties of concrete containing recron fibres and Hypo sludge. Hypo sludge was used to replace cement. They concluded that $30 \%$ replacement of cement with Hypo sludge yielded best results.

Zala L B and Umrigar F S investigated the mechanical properties of concrete with hypo sludge as a replacement material for cement. They concluded that $10 \%$ replacement of cement with hypo sludge gave highest flexural strength.

Karthickraja .R et.al, discovered the mechanical properties of concrete in which cement was practically replaced with hypo sludge. They concluded that at $10 \%$ replacement of cement with Hypo sludge yielded better Mechanical properties of concrete. 
T. Ch. Madhavi, studied Mechanical properties of concrete in which copper slag was used as a replacement material for fine aggregate. She reported that $30 \%$ replacement of fine aggregate with copper slag gave maximum strength and she reported that beyond $50 \%$ replacement the strength decreases drastically.

\section{MATERIAL PROPERTIES}

\subsection{Cement}

Ordinary Portland Cement (OPC) is composed of calcium silicates, aluminates and aluminoferrite. It is obtained by blending predetermined proportions of limestone, clay and other materials in small quantities which are pulverized and heated at high temperature around $1500^{\circ} \mathrm{C}$ to produce 'clinker'. The clinker is then ground with small quantities of gypsum to produce a fine powder called Ordinary Portland Cement. During this present work OPC conforming to IS 12269-1987 was used. Some of the physical properties of cement are listed in Table 1.

Table -1: Properties of Cement

\begin{tabular}{|l|l|}
\hline Particulars & Test value \\
\hline Fineness & $5 \%$ \\
\hline Specific gravity & 3.15 \\
\hline Consistency & $33 \%$ \\
\hline Specific gravity & 3.15 \\
\hline Initial setting time & $125 \mathrm{~min}$ \\
\hline Final setting time & $260 \mathrm{~min}$ \\
\hline
\end{tabular}

\subsection{Hypo Sludge}

Hypo sludge (HS) consumes a large percentage of local landfill space for each and every year. It is a by-product of acetylene gas plant. In this type of sludge lime varies between $25 \%$ to $50 \%$. By incinerating paper sludge at approximately $800^{\circ} \mathrm{C}$, the resultant fly ash may contain reactive silica, magnesium and alumina (in the form of Metakaolin) as well as lime $(\mathrm{CaO})$ which contributes chemical properties to the Portland cement. During this investigation Hypo sludge was used as a replacement material for cement because of both materials having Silica and Magnesium properties which improves the setting and workability properties of concrete. The properties of sludge are listed in Table 2.

Table -2: Constituent Percentage comparison between Hypo sludge \& Cement

\begin{tabular}{|l|l|l|}
\hline Constituent & \% in Sludge & \% in Cement \\
\hline Moisture & 56.8 & - \\
\hline Magnesium oxide $(\mathrm{MgO})$ & 3.3 & 1.1 \\
\hline Calcium oxide $(\mathrm{CaO})$ & 46.2 & 65.6 \\
\hline Loss on ignition & 27.00 & 0.9 \\
\hline Acid insoluble & 11.1 & 0.4 \\
\hline Silica $\left(\mathrm{SiO}_{2}\right)$ & 9.0 & 21.0 \\
\hline $\mathrm{R}_{2} \mathrm{O}_{3}$ & 3.6 & 8.66 \\
\hline
\end{tabular}

\subsection{Fine Aggregate}

Aggregates passing through $4.75 \mathrm{~mm}$ sieve are defined as fine aggregate. Fine aggregate is added to concrete to assist workability and to bring uniformity in mixture. Usually, the natural river sand is used as fine aggregate. By conducting sieve analysis, it was found that sand used for this work conforms to grading zone II as per IS 383:1970 and fineness modulus of sand was found as 2.71 . The specific gravity of fine aggregate is 2.62

\subsection{Copper Slag}

Copper slag (CS) is a by-product obtained during the copper smelting and refining process. In copper slag, $\mathrm{CaO}$ content is in the order of $0.15 \%$ to $3.30 \%$. It indicates that the lime content is very low. Slag also exhibits pozzolanic properties since it contains low $\mathrm{CaO}$. Since most of the properties of CS are similar to that of river sand, it can be used as a replacement material for sand/fine aggregate. The physical and chemical properties are listed in Table $3 \& 4$ respectively.

Table -3: Physical properties of CS

\begin{tabular}{|l|l|}
\hline Physical property & Values/nature \\
\hline Appearance & Black glassy granules \\
\hline Shape & Granular \\
\hline Specific gravity & 3.6 \\
\hline Chloride content water soluble & $11 \mathrm{ppm}$ \\
\hline Bulk Density & 1.8 \\
\hline Hardness & 7 mhos scale \\
\hline
\end{tabular}

Table -4: Chemical properties of CS

\begin{tabular}{|l|l|}
\hline Chemical property & Values \\
\hline pH of aqueous solution of aqueous extract & 6.9 \\
\hline $\mathrm{Fe}_{2} \mathrm{O}_{3}$ & $56.4 \%$ \\
\hline $\mathrm{SiO}_{2}$ & $28.7 \%$ \\
\hline $\mathrm{CaO}$ & $2.1 \%$ \\
\hline $\mathrm{Al}_{2} \mathrm{O}_{3}$ & $3 \%$ \\
\hline $\mathrm{Cu}$ & $1 \%$ \\
\hline Free moisture & $1.3 \%$ \\
\hline
\end{tabular}

\subsection{Coarse Aggregate}

Coarse aggregate is a chemically stable material present in concrete. Presence of coarse aggregate reduces the drying shrinkage and other dimensional changes occurring an account of movement of moisture. Coarse aggregate contributes to impermeability of concrete, provided that is properly graded and the mix is suitably designed. In this present work $20 \mathrm{~mm}$ angular size aggregate is used. The specific gravity of coarse aggregate is 2.67 and fineness modulus of coarse aggregate is 3.17 .

\subsection{Water}

The water, which is used for making concrete should be clean and free from harmful impurities like oil, alkalis, acids etc. Ordinary potable water available in the laboratory was used for making and curing the concrete. The quality of water was found to satisfy the requirements of IS 456-2000. 


\section{EXPERIMENTAL INVESTIGATIONS}

M25 grade mix was designed as per IS 10262-2009 and the mix proportion was found to be 1:1.80:2.95 with w/c ratio of 0.5 . Hypo sludge was used as a replacement material for cement and copper slag was as a replacement material for fine aggregate. The replacement percentage adopted were $10 \%, 20 \% \& 30 \%$ for Hypo sludge and 30\%, $40 \%$ \& $50 \%$ for copper slag. Specimens were casted and the Mechanical properties of concrete were determined.

The various percentage replacement of materials used in this present investigation are given in the Table 5:

Table -5: Details of the Specimen

\begin{tabular}{|l|l|l|l|l|}
\hline $\begin{array}{l}\text { Specimen } \\
\text { Identity }\end{array}$ & \multicolumn{4}{|l|}{ Replacements Percentages } \\
\hline Specimens & Cement & $\begin{array}{l}\text { Hypo } \\
\text { sludge }\end{array}$ & $\begin{array}{l}\text { Fine } \\
\text { aggregate }\end{array}$ & $\begin{array}{l}\text { Copper } \\
\text { slag }\end{array}$ \\
\hline A1 & 100 & 0 & 100 & 0 \\
\hline A2 & 90 & 10 & 100 & 0 \\
\hline A3 & 80 & 20 & 100 & 0 \\
\hline A4 & 70 & 30 & 100 & 0 \\
\hline B1 & 100 & 0 & 70 & 30 \\
\hline B2 & 100 & 0 & 60 & 40 \\
\hline B3 & 100 & 0 & 50 & 50 \\
\hline C1 & 90 & 10 & 70 & 30 \\
\hline C2 & 90 & 10 & 60 & 40 \\
\hline C3 & 90 & 10 & 50 & 50 \\
\hline D1 & 80 & 20 & 70 & 30 \\
\hline D2 & 80 & 20 & 60 & 40 \\
\hline D3 & 80 & 20 & 50 & 50 \\
\hline E1 & 70 & 30 & 70 & 30 \\
\hline E2 & 70 & 30 & 60 & 40 \\
\hline E3 & 70 & 30 & 50 & 50 \\
\hline
\end{tabular}

In order to investigate the mechanical property, cubes of 150 $\mathrm{mm} \times 150 \mathrm{~mm} \times 150 \mathrm{~mm}$ size, cylinders of $150 \mathrm{~mm}$ diameter and $300 \mathrm{~mm}$ length and prisms of $100 \mathrm{~mm} \times 100 \mathrm{~mm} \times 500$ $\mathrm{mm}$ were cast. The total number of specimen cast were 144 cubes, 96 cylinders and 48 prisms. The specimens were cured, and tested as per relevant codal provisions.

\subsection{Compressive Strength of Cubes}

The compressive strength of concrete were determined by conducting tests on $150 \mathrm{~mm} \times 150 \mathrm{~mm} \times 150 \mathrm{~mm}$ cube specimens at $7^{\text {th }}, 28^{\text {th }} \& 56^{\text {th }}$ days as per IS 516-1959. The test was carried out in the compression testing machine of $2000 \mathrm{kN}$ capacity. The cubes were placed in the compression testing machine and the load was applied at the rate of approximately $140 \mathrm{~N} / \mathrm{mm}^{2} / \mathrm{min}$ until the failure of the specimen. The average value of three samples were taken as strength.

\subsection{Split Tensile Strength of Cylinders}

Split tensile strength is an indirect method of finding out the tensile strength of concrete. The test is carried out by placing the cylindrical specimens horizontally between the loading surfaces of the compression testing machine and the load is applied until the failure of the cylinder, along the vertical diameter. The test was as per IS 5816:1999 on the $28^{\text {th }}$ and $56^{\text {th }}$ days.

\subsection{Flexural Strength of Prism}

Flexural strength tests were carried out on $100 \mathrm{~mm}$ x100 $\mathrm{mm} \times 500 \mathrm{~mm}$ beams on the $28^{\text {th }}$ day using a $100 \mathrm{kN}$ capacity Universal Testing Machine (UTM) apparatus. The system of loading used in finding out the flexural tension is two point loading as per IS 516-1959.

The values of the Compressive, Split tensile and Flexural strength of the specimens are given in the Table 6

Table -6: Compressive, Split tensile \& Flexural Strength Test at $7^{\text {th }}, 28^{\text {th }} \& 56^{\text {th }}$ days

\begin{tabular}{|c|c|c|c|c|c|c|c|}
\hline \multirow[b]{2}{*}{ : } & \multirow[b]{2}{*}{$\begin{array}{l}\text { \% Replacement } \\
\text { Of HS \& CS }\end{array}$} & \multicolumn{3}{|c|}{$\begin{array}{l}\text { Compressive } \\
\text { Strength }\end{array}$} & \multicolumn{2}{|c|}{$\begin{array}{ll}\text { Split } & \text { tensile } \\
\text { strength } & \end{array}$} & \multirow{2}{*}{$\begin{array}{l}\begin{array}{l}\text { Flexural } \\
\text { strength }\end{array} \\
28^{\text {th }} \text { Day } \\
\text { N/mm } \mathrm{mm}^{2}\end{array}$} \\
\hline & & $\begin{array}{l}7^{\text {th }} \text { Day } \\
\mathrm{N} / \mathrm{mm}^{2}\end{array}$ & $\begin{array}{l}28^{\text {th }} \\
\text { Day } \\
\text { N/mm }\end{array}$ & $\begin{array}{l}56^{\text {th }} \\
\text { Day } \\
\text { N/mm² }\end{array}$ & $\begin{array}{l}28^{\text {th }} \\
\text { Day } \\
\text { N/mm² }\end{array}$ & $\begin{array}{l}56^{\text {th }} \\
\text { Day } \\
\text { N/mm }\end{array}$ & \\
\hline A1 & 0 & 24.8 & 32.89 & 38.65 & 2.68 & 3.39 & 5.5 \\
\hline A2 & $10 \% \mathrm{HS}$ & 28.22 & 31.22 & 35.56 & 2.83 & 3.255 & 4.5 \\
\hline A3 & $20 \% \mathrm{HS}$ & 23.77 & 29.5 & 28.44 & 2.96 & 3.397 & 3.5 \\
\hline A4 & $30 \% \mathrm{HS}$ & 17.55 & 21.56 & 23.11 & 2.26 & 2.69 & 3.75 \\
\hline B1 & $30 \% \mathrm{CS}$ & 32.7 & 43.56 & 50 & 2.97 & 3.53 & 3.5 \\
\hline $\mathbf{B 2}$ & $40 \% \mathrm{CS}$ & 34.6 & 45.33 & 53.11 & 3.03 & 3.82 & 3 \\
\hline B3 & $50 \% \mathrm{CS}$ & 36.8 & 48.22 & 54.25 & 2.83 & 2.54 & 2.5 \\
\hline C1 & $10 \% \mathrm{HS}-30 \% \mathrm{CS}$ & 26.00 & 32.89 & 41.33 & 3.11 & 3.255 & 3.5 \\
\hline $\mathrm{C2}$ & $10 \% \mathrm{HS}-40 \% \mathrm{CS}$ & 28.44 & 34.64 & 45.4 & 3.45 & 3.11 & 5 \\
\hline C3 & $10 \% \mathrm{HS}-50 \% \mathrm{CS}$ & 31.66 & 36.31 & 36.22 & 2.83 & 2.83 & 6 \\
\hline D1 & $20 \% \mathrm{HS}-30 \% \mathrm{CS}$ & 17.55 & 31.78 & 35.67 & 3.04 & 2.83 & 5.5 \\
\hline D2 & $20 \% \mathrm{HS}-40 \% \mathrm{CS}$ & 24.22 & 33.6 & 38.74 & 3.22 & 2.97 & 4.5 \\
\hline D3 & $20 \% \mathrm{HS}-50 \% \mathrm{CS}$ & 25.33 & 33.9 & 31.24 & 2.89 & 3.11 & 4 \\
\hline
\end{tabular}




\begin{tabular}{|l|l|l|l|l|l|l|l|}
\hline E1 & $30 \%$ HS-30\%CS & 18.01 & 20 & 23.56 & 2.69 & 2.54 & 4 \\
\hline E2 & $30 \%$ HS-40\%CS & 17.29 & 21 & 25.56 & 2.97 & 2.54 & 3.5 \\
\hline E3 & $30 \%$ HS-50\%CS & 19.23 & 21.56 & 20.55 & 2.26 & 2.69 & 3 \\
\hline
\end{tabular}

\section{RESULTS AND DISCUSSIONS}

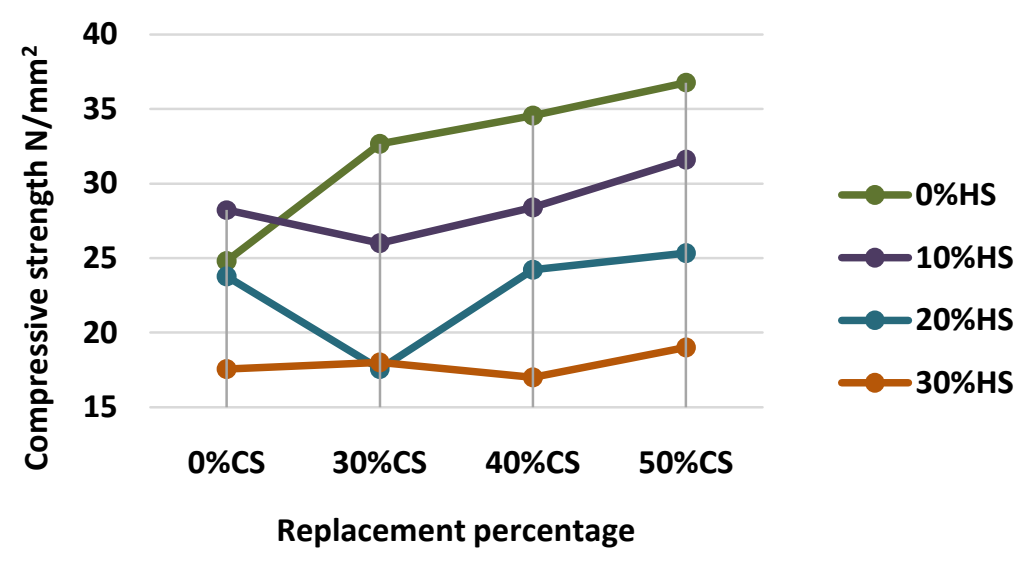

Chart -1 Compressive strength at $7^{\text {th }}$ day

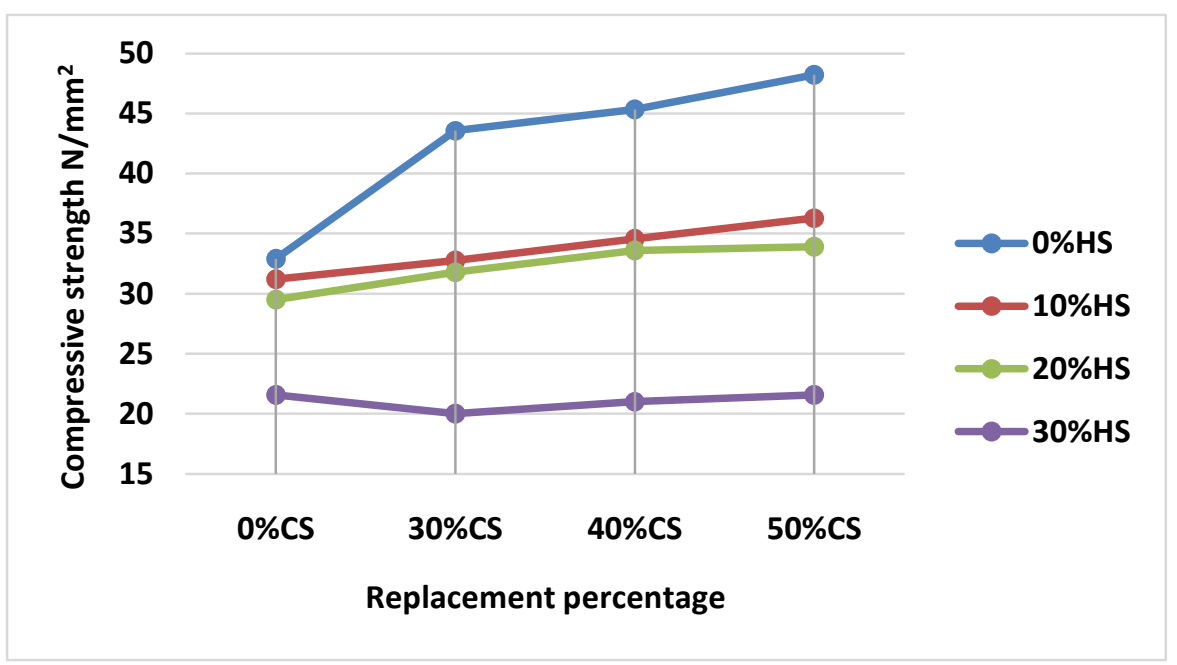

Chart -2 Compressive strength at $28^{\text {th }}$ day

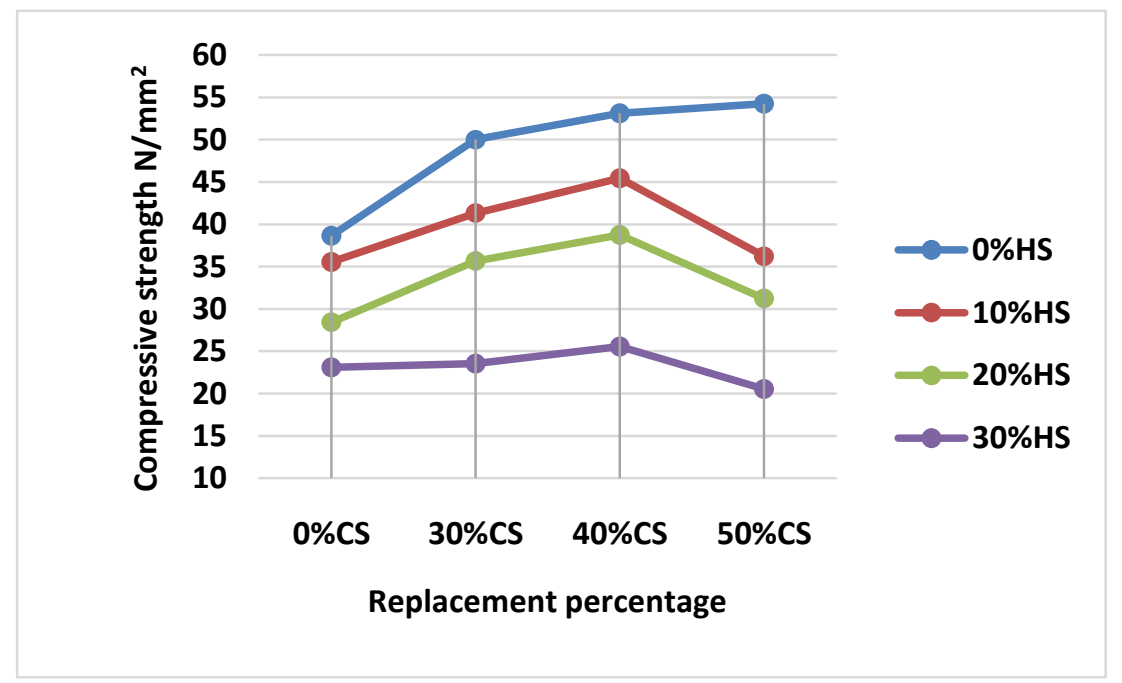

Chart -3 Compressive strength at $56^{\text {th }}$ day 


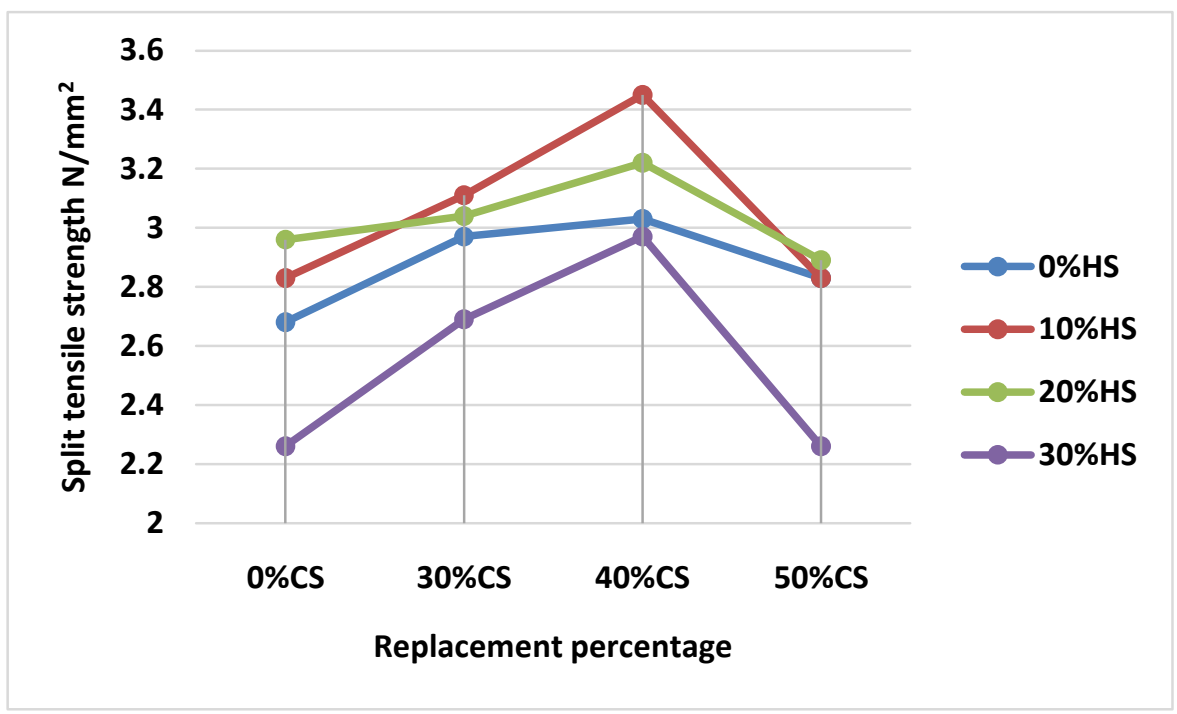

Chart $\mathbf{- 4}$ Split tensile strength at $28^{\text {th }}$ day

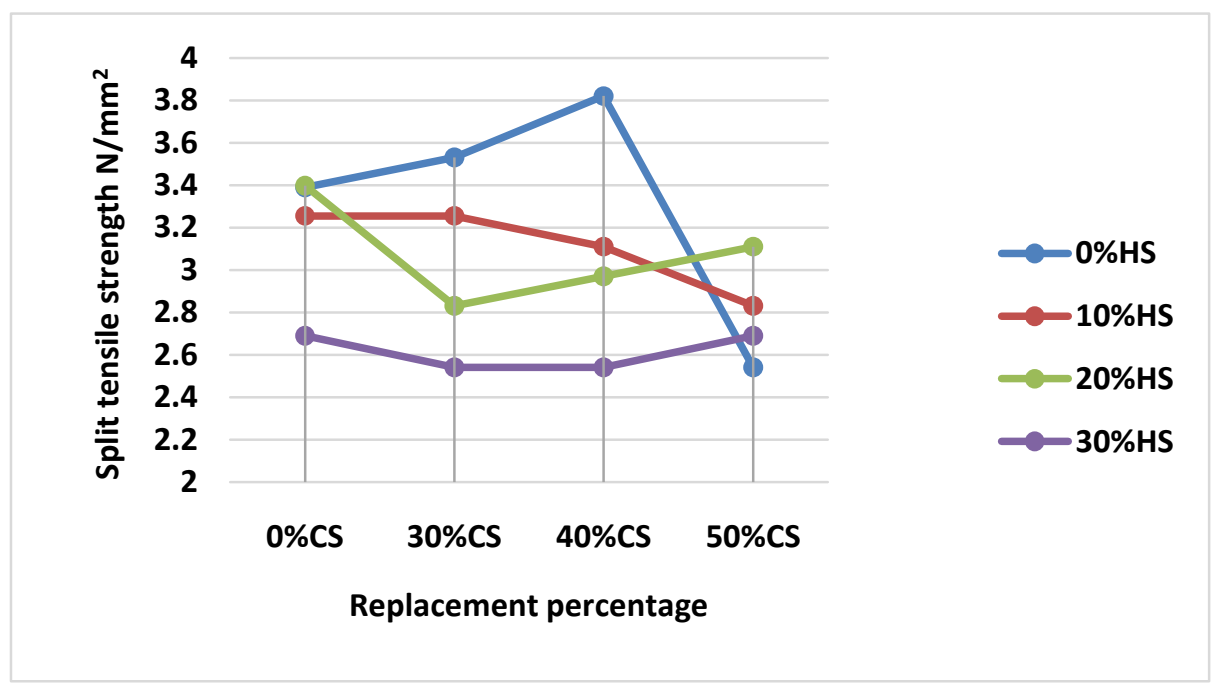

Chart $\mathbf{- 5}$ Split tensile strength at $56^{\text {th }}$ day

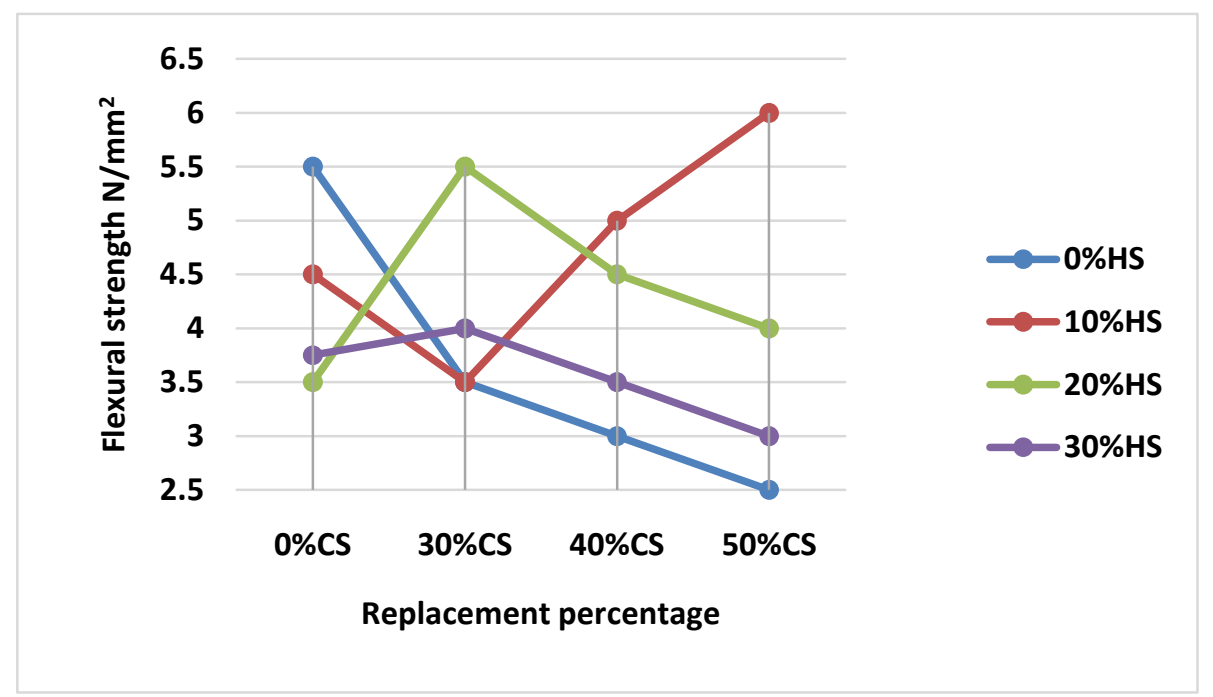

Chart -6 Flexural strength at $28^{\text {th }}$ day 


\section{CONCLUSION}

1. Optimum of $50 \%$ replacement of fine aggregate by copper slag shows increase in compressive strength when compared to conventional mix.

2. With $10 \%$ replacement of cement by Hypo sludge shows increase in compressive strength when compared to $20 \%$ and $30 \%$ replacement mix.

3. Optimum of $10 \%$ replacement of cement with Hypo sludge and 50\% replacement of fine aggregate with Copper slag shows increase in compressive strength compared to other combinations.

4. $10 \%$ and $20 \%$ replacement of cement with HS shows little variation in compressive strength based on curing days.

5. With increase in curing days $40 \%$ replacement of fine aggregate with copper slag shows increase in split compressive strength.

6. Optimum of $10 \%$ replacement of cement with Hypo sludge and $40 \%$ replacement of fine aggregate with Copper slag shows increase in split tensile strength compared to conventional mix.

7. At $40 \%$ replacement of fine aggregate by copper slag shows increase in split strength.

8. With increase in curing days $30 \%$ replacement of cement with hypo sludge shows decrease in split tensile strength when compared to other combinations.

9. Optimum of $10 \%$ replacement of cement with Hypo sludge and 50\% replacement of fine aggregate with Copper slag shows increase in flexural strength compared to conventional mix.

\section{REFERENCES}

[1] Jayeshkumar pitroda, 1 b zala \& f s umrigar (2013), "A techno-economic study on paper industry wastehypo sludge concrete in rigid pavement" in International Journal of Civil, Structural, Environmental and Infrastructure Engineering Research and Development (IJCSEIERD), Vol. 3, Issue 5, pp.133-144.

[2] Srinivasan .R, Sathiya .K and Palanisamy .M (2010), "Experimental investigation in developing low cost concrete from paper industry waste" in Buletinul institutului politehnic din iaşi tomul lvi (lx) fasc.1, pp: 44-56.

[3] Balamurugan .R, Karthickraja .R (2014), “An experimental investigation of partial replacement of cement by industrial waste (hypo sludge)" in Int. Journal of Engineering Research and Applications, Vol. 4, Issue 4, pp.430-435.

[4] Ashwini .A, Pavitha .G, Dharani .N and PrinceArulraj .G (2013), "Experimental investigation on mechanical Properties of Recron $3 \mathrm{~s}$ fiber reinforced hypo sludge Concrete" in International journal of civil engineering and Technology, Volume 4, Issue 1, January- February (2013), pp. 182-189.

[5] Brindha .D and Nagan .S (2010), "Utilization of copper slag as a partial replacement of fine aggregate in concrete" in International Journal of Earth Sciences and Engineering (2010), Vol. 03, No. 04, pp. 579-585.
[6] Chavan R R \& Kulkarni D B (2013), "Performance of copper slag on strength Properties as partial replace of fine aggregate In concrete mix design" in International Journal of Advanced Engineering Research and Studies, Vol. II, pp.95-98

[7] Hemanth, Balakrishna H.B (2013), "Flexural behavior of RC beams with partial replacements of slag sand with river sand and fly ash with cement" in International Journal of Emerging Trends in Engineering and Development Issue 3, Vol.5, pp. 7585.

[8] Vimarsh S.P, Basavana Gowda S.N, Ramesh B.R (2014), "Study on strength properties of fibre reinforced concrete by partial replacement of sand by copper slag" in International Journal of Civil and Structural Engineering Research, Vol. 2, Issue , pp: 104-110.

[9] Zala L.B, Umrigar F.S (2013), Experimental investigation of the usage of hypo sludge as partial replacement of cement on the mechanical properties of concrete" in Journal of international academic research for multidisciplinary "volume 1 , issue 10 , and pp: 339-349.

[10] Arivalagan .S (2013), "Experimental Study on the Flexural Behavior of Reinforced Concrete Beams as Replacement of Copper Slag as Fine aggregate" in Journal of Civil Engineering and Urbanism, Volume 3, Issue 4: 176-182, pp: 176-182.

[11] Shetty M.S., "Concrete Technology Theory and Practice", S. Chand \& Company, New Delhi

[12] IS: 383-1970, Specifications for Coarse and Fine Aggregates from Natural Sources for Concrete, Bureau of Indian Standards, New Delhi, India.

[13] IS: 10262-2009, Recommended Guidelines for Concrete Mix Design, Bureau of Indian Standards, New Delhi, India.

[14] IS: 516-1959, Indian Standard Code of PracticeMethods of Test for Strength of Concrete, Bureau of Indian Standards, New Delhi, India.

[15] IS: 456-2000. "Code of practice for plain and reinforced concrete", bureau of Indian standards. New Delhi.

\section{BIOGRAPHIES}

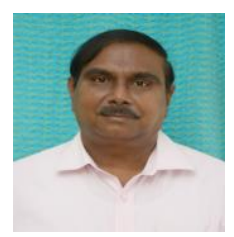

Dr. G. Prince Arulraj, Professor \& Dean, Department of Civil Engineering and COE in SNS College of Technology, Coimbatore. He completed B.E Civil Engineering in Thiyagarajar Engineering, Madurai. M Tech and Ph.D. at IIT Madras. He is having 30 years of Teaching Experience. His fields of interest are Self- compacting concrete, selfhealing concrete, fire resistance of concrete and applications of GIS in Civil Engineering 
N. Dharani, Assistant Professor, SNS

College of Technology, Coimbatore. She completed B.E Civil engineering at PSG College of Technology, Coimbatore. M.E Structural Engineering at Govt. College of Technology, Coimbatore. She is having 3 years of experience as Assistant Professor.

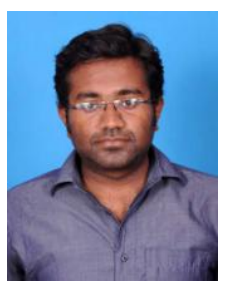

J. Goutham, PG Student (Structural Engineering), SNS College of Technology, Coimbatore. Completed B.E Civil Engineering at Tamil Nadu College of Engineering, Coimbatore. 